(C) 1997 The Chemical Society of Japan

\title{
2-アミノピリジンー酢酸系の励起状態における 互変異性に対する分子軌道法による考察
}

(1997 年 1 月 28 日受理)

犬塚功三

2-アミノピリシンー酶酸系の励起状態に扔ける異性化反応機構を明らかにするために，比較的計算の 容易な 2-アミノピリジンーギ酸系をモデルとして, 構造最適化を含めた 6-31G 基底関数を用いた非経 験的分子軌道法による計算を行い，つぎのような結果を得た．（1）2-アミノピリシンーギ酸複合体(ア ミノ体と略)，2-アミノピリジニウムーギ酸塩(カチオン体と略)ならびに $2(1 H)$-ピリシンイミンーキ酸 複合体 (イミノ体と略)の最低励起一重項状態はいずれも $\pi, \pi^{*}$ 状態である. (2) 最低励起一重項状態に おける安定性の順序はイミノ体>カチオン体>アミノ体となっている．この順序は基底状態のそれと逆 である. (3) アミノ体からイミノ体への互変異性化反応過程のポテンシャルエネルギー曲面の計算結果 では, アミノ体からイミノ体へのダブルプロトン移動によって, 一段階で異性化するためには途中に高 いポテンシャル障壁があるので困難である.アミノーイミノ互変異性化反応の最適経路はアミノ体-> カチオン体->イミノ体の経路が最もポテンシャル障壁が低く最適である.すなわち，カチオン体を反 応中間体としてアミノーイミノ互変異性化反応は進行する. (4) 2-アミノピリシンン-酢酸系の蛍光スペ クトルの挙動では, 酢酸濃度が低いときは三つの複合体間の安定性は前述のイミノ体>カチオン体>ア ミノ体の順序であるが, 酢酸濃度が高くなると安定性の順序はカチオン体〉イミノ体〉アミノ体とな る、このことは酢酸濃度の増加によって溶媒の電場の効果が極性の大きなカチオン体に大きく作用し て, イミノ体よりも大きく安定化するためと考えられる。このため, 酢酸濃度が低いときはイミノ体の 蛍光が現れ，酢酸濃度が高くなるにつれてカチオン体の蛍光へ変化する.

\section{1 序論}

先に 2-アミノピリジン-酭酸系に対するUV スペクトルの測定 から, 基底状態に打いてアミノーイミノ互変異性により $2(1 H)-$

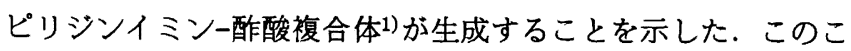
とは $2(1 H)$-ピリシンイミンのモデルと考えられる1-メチル$2(1 H)$-ピリシンイミン2)の UV スペクトルの測定と分子軌道法 に基づく考察から, その生成を明らかにした，さらに最近プロト ン移動によって2-アミノピリシニウムー酷酸塩3の生成を赤外ス ペクトルの測定結果と分子軌道法に基づく計算結果から考察し た. 基底状態の 2-アミノピリシンー酢酸系に打いては，水素結合 体からプロトン移動によって2-アミノピリジニウム眽酸塩が生 成し，この 2-アミノビリシニウム塩を反応中間体として $2(1 H)-$ ピリジンイミンー酢酸複合体が生成することを分子軌道法の計算 結果3)は示している。しかしながら，基底状態では 2-アミノピ リシンン酢酸複合体や 2-アミノピリシニウム塩の生成に比べて, $2(1 H)$-ピリシンイミンー酶酸複合体の生成了)は困難である.

先に，2-アミノピリシンのイソオクタン溶液に酢酸を添加し

東京電機大学工学部物質工学科, 101 東京都千代田区神 田錦町 2-2
たときの蛍光スペクトルの変化)を調べた．それによると 326 $\mathrm{nm}$ に $\lambda_{\max }$ をつ2-アミノピリシンの蛍光スペクトルは酢酸添 加とともに急激にその強度を減じるが，その $\lambda_{\max }$ の位置は変化 しない.これとともに, $420 \mathrm{~nm} に \lambda_{\max }$ をつブロードであるが 振動構造をもつ $2(1 H)$-ピリジンイミン一酢酸複合体による蛍光 スペクトルが現れるが，さらに䣫酸添加が進むと，360 nmk $\lambda_{\max }$ をつ 2-アミノピリジニウム酢酸塩による蛍光スペクトル へと変化する.このような一連の蛍光スペクトルの変化は基底状 態で生成した 2 -アミノピリシンー酢酸水素結合体は最低 $\pi, \pi^{*}$ 一 重項状態に励起されると, ダブルプロトン移動によって $2(1 H)-$ ピリシンイミンー酶酸複合体を生じ，酢酸莀度が增加するとこの 複合体から 2-アミノピリシニウムー眽酸塩を生成するという機 構4)で解釉した。

最近, Zwail ら5)は $1 H$-ピロロ[2,3-b]ビリシンの励起状態におう ける互変異性化反応についてフェムト秒の時間単位で, $1 H$-ビロ ロ[2,3-b]ピリシン二量体のプロトン移動の測定を行い，異性化 反応機構を考察した．ZWail ら5)によれば励起された $1 H$-ピロロ [2,3-b]ピリジン二量体はプロトン移動によって dipolar 型の中 間体を形成し，ついで，その中間体はブロトン移動によって互変 異性体を形成する機構を提出した。すなわち，塩基二量体 
-.>>dipolar 型の中間体 $\cdots>$ 互変異性体という機構である．この 機構は先に基底状態の 2-アミノピリシン一酢酸系に抢ける 2-ア ミノピリジニウムー酢酸塩を中間体とする互変異性化反応に対す る分子軌道法による考察3 と類似している.

この論文では，酢酸の代わりにキ酸を用いた 2 -アミノビリジ ンーキ酸系をモデルとして, 最低励起 $\pi, \pi^{*}$ 一重項状態に打ける 互変異性化反応機構を分子軌道法を用いて調べ，2-アミノピリ シンー酢酸系の蛍光スペクトルで観察されるスペクトル挙動に対 する先の解秎はを再検討した。

\section{2 計算方法と計算に用いたモデル}

Fig. 1 に示した各モデルに対し，最低励起一重項状態に打ける 最適構造と全エネルギーを構造最適化を含めた Gaussian 型原子 軌道の 6-31G 基底関数を用いた非経験的分子軌道法を用いた CIS 法で計算した. Fig. 1 に示した 2-アミノピリシンノギ酸複合 体(アミノ体と略)，2-アミノピリシニウムーキ酸塩(カチオン体 と略)，2(1H)-ピリシンイミン-ギ酸複合体(イミノ体と略)に対 する各モデルの各原子は同一平面上にあると仮定した．したがっ て, 最適構造を決定するために必要な構造パラメーターの数は 33 個となった．計算には Gaussian 94ソースブログラム6)を用

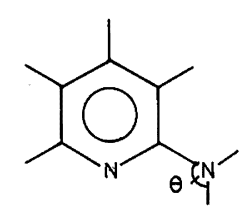

(1)

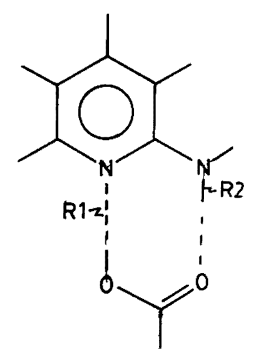

(3)

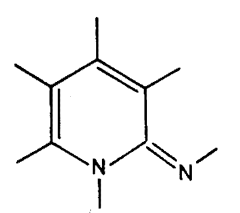

(2)

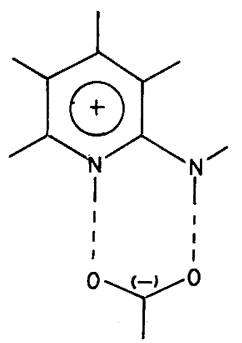

(4)

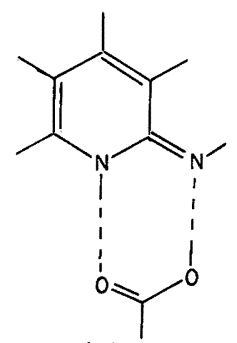

(5)
Fig. 1 The molecular models used for the present calculation:

(1) 2-aminopyridine, (2) $2(1 H)$-pyridinimine, (3) 2aminopyridine-formic acid complex, (4) 2-aminopyridinium formate complex, and (5) $2(1 \mathrm{H})$-pyridinimine-formic acid complex.
い，本学計算センターのCray J916 電子計算機で行った．CIS 法による励起状態に抢ける構造最適化によるエネルギー計算は基 底状態に抢ける計算と比べて，cpu とメモリーを非常に多く必要 とするので，この計算に用いた大きさのモデルに対しては 6$31 \mathrm{G}$ (d) 基底関数や，さらに好ましい $6-31+\mathrm{G}(\mathrm{d})$ 基底関数の使 用は本学計算センターでは実行困難であったので 6-31G 基底関 数を使用した。

\section{3 計算結果と考察}

Fig. 1 に示した各モデルの最低励起一重項状態 $\left(\mathrm{S}_{1}\right)$ における最 適構造に対する全エネルギー $\left(E_{\mathrm{T}}\right)$ ，遷移エネルギー $(E)$ ，最大 吸収波長 $\left(\lambda_{\max }\right)$, 振動子強度 $(f)$ ならびに励起状態に抢ける双極 子モーメント $(\mu)$ の值を Table 1 に示した。これらの各モデルの $\mathrm{S}_{1}$ 状態はすべて $\pi, \pi^{*}$ 状態となった. 2-アミノピリシンの励起状 態に対する $\mathrm{CNDO} / \mathrm{CI}$ 法による計算(4)7) では $\mathrm{S}_{1}$ 状態は $\mathrm{n}, \pi^{*}, \mathrm{~S}_{2}$ 状態は $\pi, \pi^{*}$ が得られて抢り，現在の計算結果とは逆になってい

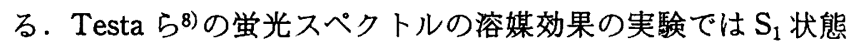
は $\mathrm{n}, \pi^{*}$ と考えられているが，両状態は接近していることを示し ている．2-アミノピリジン，アミノ体，カチオン体，イミノ体 の各モデルの最適構造を Fig. 2 に示した. $\mathrm{S}_{1}$ と $\mathrm{S}_{0}$ 状態の $2-ア$ ミノピリシンの構造を比べるとピリシン環の各結合距離は長くな るのに対し， C- $\mathrm{NH}_{2}$ 結合は短くなっている. カチオン体の $\mathrm{S}_{1}$ と $\mathrm{S}_{0}$ 状態の構造を比較すると， $\mathrm{S}_{1}$ 状態ではイミノ基の $\mathrm{N}-\mathrm{H}$ 結合 は短くなるのに対し，アミノ基の $\mathrm{N}-\mathrm{H}$ 結合は長くなっている. また $\mathrm{C}-\mathrm{NH}_{2}$ 結合は短くなり，イミノ構造へ異性化しやすいこと を示している. Table 1 に示した各モデルの吸収帯の $\lambda_{\max }$ の計 算値はいずれも測定值と比べて短波長側にあるが，各複合体と 2-アミノピリシンのの吸收帯の位置の順序は妥当な傾向を示して いる. Table 1 の計算結果は $\mathrm{S}_{1}$ 状態では 2-アミノピリシンはア ミノ形よりイミノ形のほうが $32.3 \mathrm{~kJ} \mathrm{~mol}^{-1}$ エネルギー的に安定 であることを示して抢り，基底状態 $\left(\mathrm{S}_{0}\right)^{3)}$ とは逆の傾向を示して いる. したがって，2-アミノピリシンの隣接したアミノ基の $\mathrm{H}$ 原子が同一面内でピリシン環の $\mathrm{N}$ 原子の方へ移動すると考えて, Fig. 1(1)に示した 2-アミノピリシンモデルの結合角 $\theta$ をアミノ形 $\left(115.0^{\circ}\right)$ 加イミノ形 $\left(60.5^{\circ}\right)$ になるまで変化したときの, 全エネ ルギー変化を計算すると Fig. 3 に示すようなポテンシャル曲線 を得た．ポテンシャル障壁は $\theta=75^{\circ}$ のとき $194.6 \mathrm{~kJ} \mathrm{~mol}^{-1}$ とな り, 非常に高く, 2-アミノピリシンが $\mathrm{S}_{1}$ 状態で直接イミノ体へ 異性化することは困難と思われる.

$\mathrm{S}_{1}$ 状態に打ける 2-アミノピリシン環の $\mathrm{N}$ 原子の電荷密度の計

Table 1 Calculated total energies $\left(E_{\mathrm{T}}\right)$, transition energies $(E)$, maximum wavelength $\left(\lambda_{\max }\right)$, oscillator strengths $(f)$, and dipole moments $(\mu)$ of the optimized models of 2-aminopyridine, $2(1 H)$-pyridinimine, 2-aminopyridine-formic acid complex, 2 aminopyridinium formate complex, and $2(1 H)$-pyridinimine-formic acid complex in the lowest excited $\pi, \pi^{*}$ singlet state by the $\mathrm{ab}$ initio $6-31 \mathrm{G}$ MO method

\begin{tabular}{|c|c|c|c|c|c|c|}
\hline Model & $E_{\mathrm{T}} /$ a.u. & $E / \mathrm{eV}$ & $\lambda_{\max } / \mathrm{nm}$ & $f$ & $\mu / \mathrm{D}$ & $\lambda_{\mathrm{obs}} / \mathrm{nm}$ \\
\hline 2-Aminopyridine & -301.39967 & 5.609 & 221 & 0.159 & 2.686 & $290^{\mathrm{a})}$ \\
\hline $2(1 H)$-pyridinimine & -301.41200 & 4.270 & 290 & 0.204 & 1.452 & \\
\hline 2-Aminopyridine-formic acid complex & -490.10173 & 5.370 & 230 & 0.184 & 2.572 & \\
\hline 2-Aminopyridinium formate complex & -490.10693 & 5.097 & 243 & 0.225 & 7.212 & $305^{a)}$ \\
\hline $2(1 H)$-pyridinimine-formic acid complex & -490.10897 & 4.566 & 271 & 0.211 & 1.683 & $335^{b)}$ \\
\hline
\end{tabular}

a) Ref.(4). b) Ref.(1). 


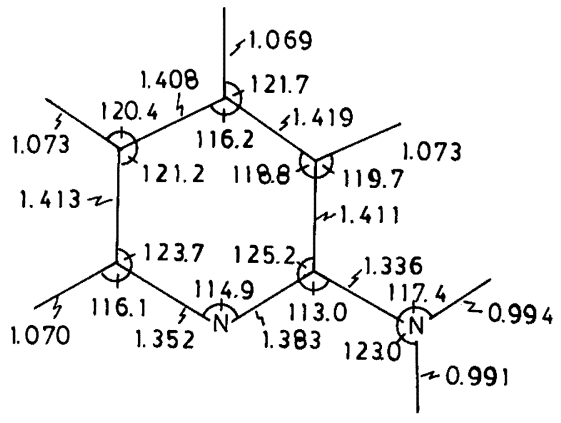

(a)

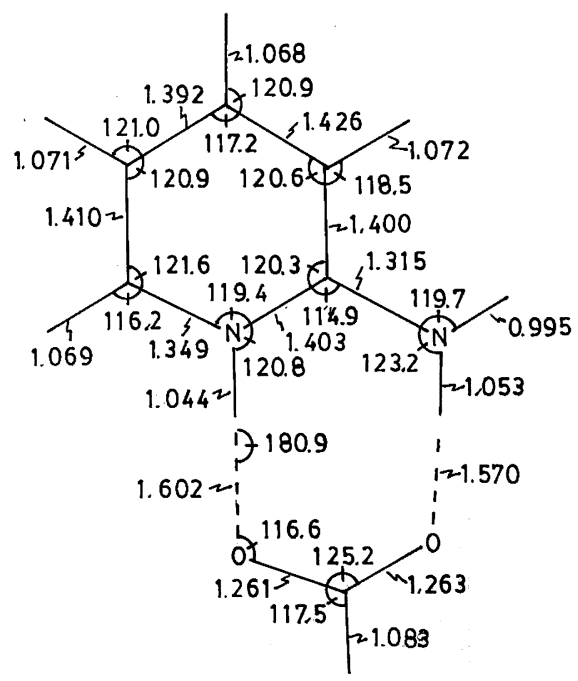

(c)

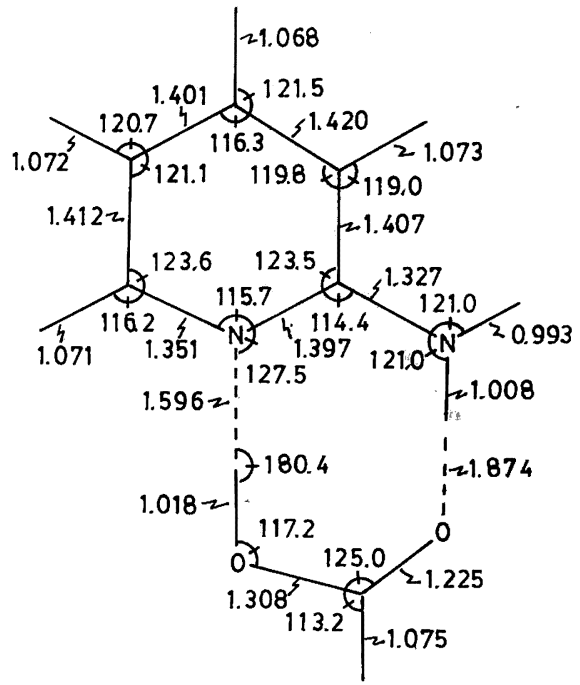

(b)

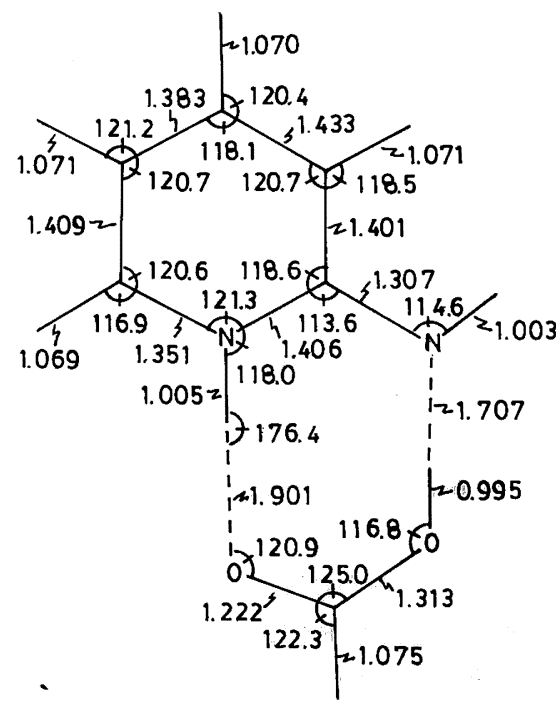

(d)

Fig. 2 The optimized geometries of models: (a) 2-aminopyridine. (b) 2-aminopyridine-formic acid complex, (c) 2-aminopyridinium formate complex, and (d) $2(1 H)$-pyridinimine-formic acid complex in the $\mathrm{S}_{1}$ state.

算値は一0.656となり， $\mathrm{S}_{0}$ 状態の值 $(-0.625)$ と比べて增加して いる.このことは $\mathrm{S}_{1}$ 状態に打いて 2-アミノピリジンの塩基性は 增加し，プロトン付加能力が增加することを示している.ささらに。 2-アミノピリシンのの酢酸との水素結合に関与するアミノ基のH原 子の電荷密度の値は $\mathrm{S}_{1}$ 状態では $0.388, \mathrm{~S}_{0}$ 状態では 0.383 となっ ている. 電荷密度の変化から，2-アミノピリジンは $\mathrm{S}_{1}$ 状態にお いて酢酸との水素結合能力が増大することを示唆している．この ことは Fig. 2 に示した $\mathrm{S}_{1}$ 状態のアミノ体の最適構造と $\mathrm{S}_{0}$ 状態3) のそれを比較すると， $\mathrm{S}_{1}$ 状態ではピリシン環の $\mathrm{N}$ 原子とギ酸の $\mathrm{COOH}$ 基の $\mathrm{H}$ 原子間の距離 $\left(1.596 \AA\left(\mathrm{S}_{1}\right) / 1.685 \AA\left(\mathrm{S}_{0}\right)\right)$ は短く なるのに対し，栖夋の $\mathrm{O}-\mathrm{H}$ 間の距離 $\left(1.018 \AA\left(\mathrm{S}_{1}\right) / 0.999 \AA\left(\mathrm{S}_{0}\right)\right)$ は長くなることで理解される.ここで, Table 1 の全エネルギー の計算值から $\mathrm{S}_{1}$ 状態に抢けるアミノ体，カチオン体打よびイミ ノ体の安定性を比較すると，その安定性の順序は アミノ体くカ チオン体くイミノ体 となって抢り，イミノ体が最む安定であ
る.これに対し， $\mathrm{S}_{0}$ 状態3)ではアミノ体>カチオン体>イミノ体 となっている.

$\mathrm{S}_{1}$ 状態に打けるアミノーイミノ互変異性の反応経路を明らかに するために, Fig. 1(3)に示したアミノ体モデルの罢 N 原子とギ酸 の $\mathrm{COOH}$ 基の $\mathrm{H}$ 原子間距離( $\mathrm{R} 1$ ) と $\mathrm{NH}_{2}$ 基の $\mathrm{N}-\mathrm{H}$ 間距離( $\left.\mathrm{R} 2\right)$

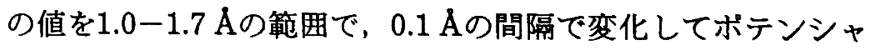
ルエネルギー変化を計算した. Table 2 に距離 R1 と R2 に対し て計算した全エネルギーをアミノ体の全エネルギー (-490.10173 a.u.) 基準として示している. Table 2 から二つ の反応経路が存在することが明かである. 第一の経路は R1 に沿 っており，これはアミノ体からカチオン体へのブロトン移動の释 路である．第二の経路は R2 に沿って打り，カチオン体からイミ ノ体へのアミノーイミノ互変異性に対応している.

Table 2 からつぎのことが考えられる．(1)経路 R1 に沿って反 応が進行するときは原子間距離 R2 の値はほとんど一定(約 1.0 


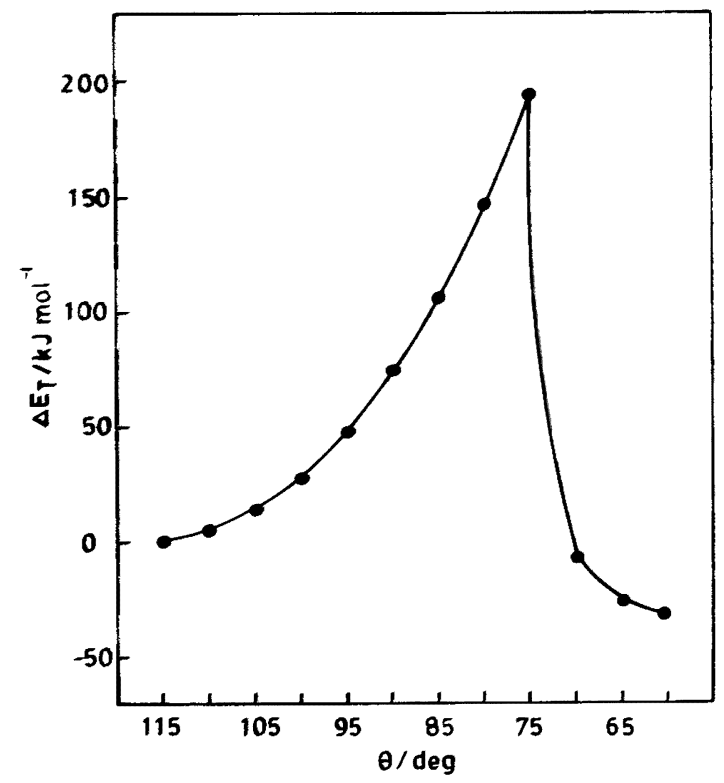

Fig. 3 The potential energy curve of amino-imino tautomerization process from 2-aminopyridine to $2(1 \mathrm{H})-$ pyridinimine against the angle $(\theta)$ in the $S_{1}$ state.
Table 3 The potential energy changes of the optimized model of 2-aminopyridine-formic acid complex were calculated against the atomic distance, $R 1$ in the complex in the $S_{1}$ state by the ab initio $6-31 G$ MO method

\begin{tabular}{cccccc}
\hline No. & $\mathrm{R} 1 / \AA$ & $\mathrm{R} 2 / \AA$ & $E_{\mathrm{T}} / \mathrm{a} . \mathrm{u}$. & $\Delta E_{\mathrm{T}} / \mathrm{kJ} \mathrm{mol}{ }^{-1}$ & $\mu / \mathrm{D}$ \\
\hline 1 & 1.700 & 1.006 & -490.10142 & 0.813 & 0.215 \\
$2^{\text {2) }}$ & 1.596 & 1.008 & -490.10173 & 0.000 & 2.572 \\
3 & 1.500 & 1.009 & -490.10144 & 0.760 & 3.009 \\
4 & 1.400 & 1.012 & -490.10071 & 2.677 & 3.600 \\
5 & 1.300 & 1.017 & -490.10029 & 3.778 & 4.451 \\
6 & 1.250 & 1.022 & -490.10069 & 2.728 & 5.000 \\
7 & 1.200 & 1.027 & -490.10183 & -0.263 & 5.617 \\
8 & 1.170 & 1.031 & -490.10288 & -3.016 & 6.002 \\
9 & 1.150 & 1.035 & -490.10369 & -5.142 & 6.241 \\
10 & 1.100 & 1.043 & -490.10573 & -10.498 & 6.777 \\
11 & 1.080 & 1.046 & -490.10638 & -12.201 & 6.958 \\
$12^{\text {b) }}$ & 1.044 & 1.053 & -490.10693 & -13.648 & 7.212 \\
13 & 1.020 & 1.057 & -490.10664 & -12.886 & 7.351 \\
14 & 1.000 & 1.060 & -490.10585 & -10.813 & 7.458 \\
\hline
\end{tabular}

a) No. 2 corresponds to the amino complex.

b) No. 12 corresponds to the cation complex.

A)である. (2)同様に，経路 R2 に沿って進行するときは R1 の值 がほとんどー定(約 $1.0 \AA$ )である.

以上のことで重要なことは, Table 2 の結果はアミノ体モデル のキ酸のプロトンとアミノ基のプロトンが同時にタフフルプロトン 移動によって，アミノ体加直接イミノ体を生成する反応過程は 高いボテンシャル障壁が存在してエネルギー的に困難であること を示している．したがって，酶酸を用いた場合む同様であると考 えられる。

(1) カチオン体の生成過程を明らかにするために， $\mathrm{S}_{1}$ 状態の アミノ体モテルの全エネルギーを距離 R1に対して計算した。こ のときの R1 の值に対する $\mathrm{R} 2$ の最適値, 全エネルギー $\left(E_{\mathrm{T}}\right)$, 双枢子モーメント $(\mu)$ の值を Table 3 に示した. Table 3 で明ら かなようにR1の変化に対し，R2 の値は余り変化していない.

Fig. 4 にアミノ体の全エネルギーを基準としてエネルキー差 $\Delta E_{\mathrm{r}}$ を距離 R1 に対してフフロットした. Fig. 4 において, $1.30 \AA$

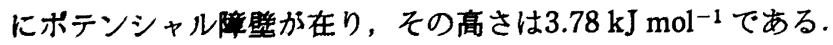

1.044 Aの观にポテンシャルミニマムが存在しており, この位置

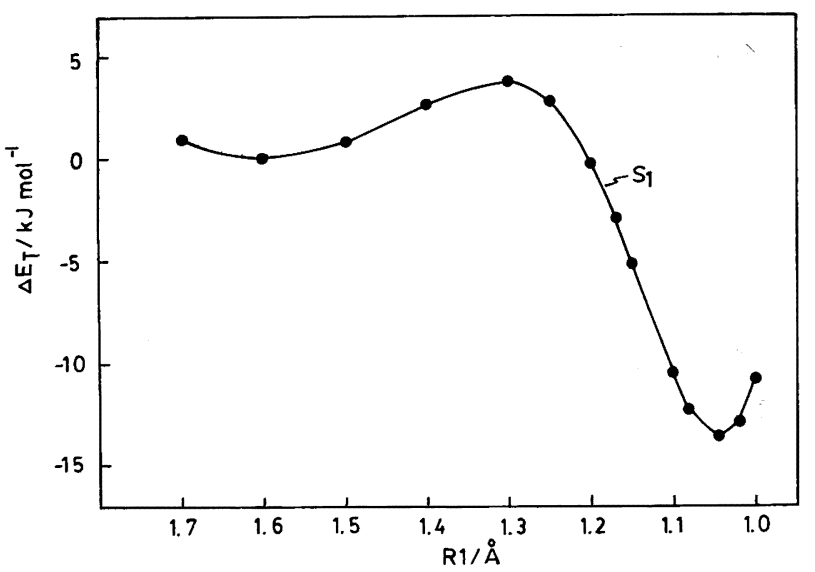

Fig. 4 The potential energy curve of proton-transfer process from 2-aminopyridine-formic acid complex to 2-aminopyridinium formate complex against the atomic distance $R 1$ in the $S_{1}$ state.

Table 2 The potential energy changes of the optimized model of the 2-aminopyridine-formic acid complex were calculated against the atomic distances $(\AA), R 1$ and $R 2$. In the 2-aminopyridine-formic acid complex in the $S_{1}$ state by the ab initio 6-31G MO method. The calculated energies were based on the energy of the most stable 2-animopyridine-formic acid complex in the $\mathrm{S}_{1}$ state and represented in $\mathrm{kJ} \mathrm{mol}^{-1}$

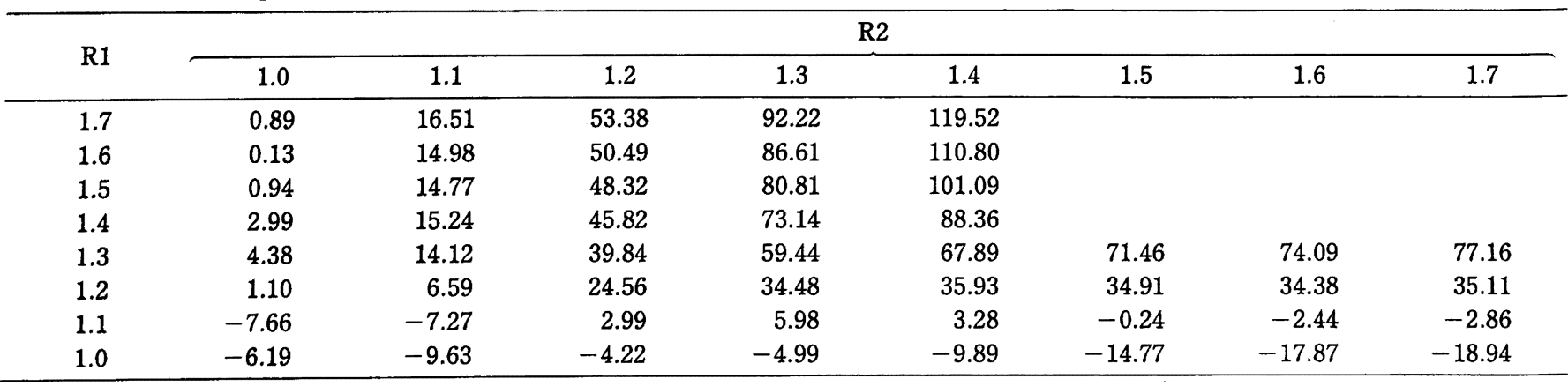


はカチオン体の環 $\mathrm{N}$ 原子とプロトン間の $\mathrm{N}-\mathrm{H}$ 距離に対応してい る. $\mathrm{S}_{1}$ 状態に括けるアミノ体からカチオン体へのプロトン移動 のポテンシャル障壁は $\mathrm{S}_{0}$ 状態におけるポテンシャル障壁 $(13.10$ $\mathrm{kJ} \mathrm{mol}^{-1}$ ) と比べて非常に低い.さらに $\mathrm{S}_{0}$ 状態のプロトン移動の 場合と異なり, カチオン体の方がアミノ体よりも $13.65 \mathrm{~kJ} \mathrm{~mol}^{-1}$ 安定であることが注目される. Fig. 4 に示したボテンシャル曲線 の形状から，アミノ体からカチオン体への異性化は非常に容易で あると考えられる。

（2） カチオン体からイミノ体への異性化反応に対するポテンシ ヤルエネルギー曲線を得るために，距離 R2 を変化して複合体の 全エネルギーを計算した．このときの R2 の值に対する R1 の最 適値, 全エネルギー $\left(E_{\mathrm{T}}\right)$, 双極子モーメント $(\mu)$ の值を Table 4 に示した. Table 4 に示すように R2 の変化に対し， R1 の値は $0.05 \AA$ A内の変化に過ぎない. Table 4 中にカチオン体と複合体 の間の全エネルギー差 $\Delta E_{\mathrm{T}}(1)$ とアミノ体と複合体の間の全エネ ルギー差 $\Delta E_{\mathrm{T}}(2)$ を示した. Fig. 5 にエネルギー差 $\Delta E_{\mathrm{T}}(1)$ を距

Table 4 The potential energy changes of the optimized model of 2-aminopyridine-formic acid complex were calculated against the atomic distance, $\mathrm{R} 2$ in the complex in the $S_{1}$ state by the ab initio 6-31G MO method

\begin{tabular}{ccccccc}
\hline No. & $\mathrm{R} 2 / \AA$ & $\mathrm{R} 1 / \AA$ & $E_{\mathrm{T}} / \mathrm{a} . \mathrm{u}$. & $\begin{array}{c}\Delta E_{\mathrm{T}}(1) / \\
\mathrm{kJ} \mathrm{mol}-1\end{array}$ & $\begin{array}{c}\Delta E_{\mathrm{T}}(2) / \\
\mathrm{kJ} \mathrm{mol}\end{array}$ & $\mu / \mathrm{D}$ \\
\hline $1^{\mathrm{a})}$ & 1.053 & 1.044 & -490.10693 & 0.000 & -13.648 & 7.212 \\
2 & 1.100 & 1.037 & -490.10623 & 1.836 & -11.812 & 6.752 \\
3 & 1.150 & 1.029 & -490.10482 & 5.535 & -8.113 & 6.133 \\
4 & 1.200 & 1.023 & -490.10372 & 8.422 & -5.226 & 5.425 \\
5 & 1.250 & 1.018 & -490.10341 & 9.234 & -4.414 & 4.746 \\
6 & 1.300 & 1.015 & -490.10380 & 8.213 & -5.435 & 4.162 \\
7 & 1.350 & 1.012 & -490.10461 & 6.088 & -7.560 & 3.672 \\
8 & 1.400 & 1.010 & -490.10559 & 3.514 & -10.134 & 3.254 \\
9 & 1.500 & 1.008 & -490.10741 & -1.259 & -14.907 & 2.609 \\
10 & 1.600 & 1.006 & -490.10857 & -4.305 & -17.953 & 2.109 \\
$11^{\text {b) }}$ & 1.707 & 1.005 & -490.10897 & -5.355 & -19.003 & 1.683 \\
12 & 1.750 & 1.005 & -490.10891 & -5.196 & -18.844 & 1.536 \\
13 & 1.800 & 1.004 & -490.10872 & -4.697 & -18.345 & 1.365 \\
\hline
\end{tabular}

a) No. 1 corresponds to the cation complex.

b) No. 11 corresponds to the imino complex.

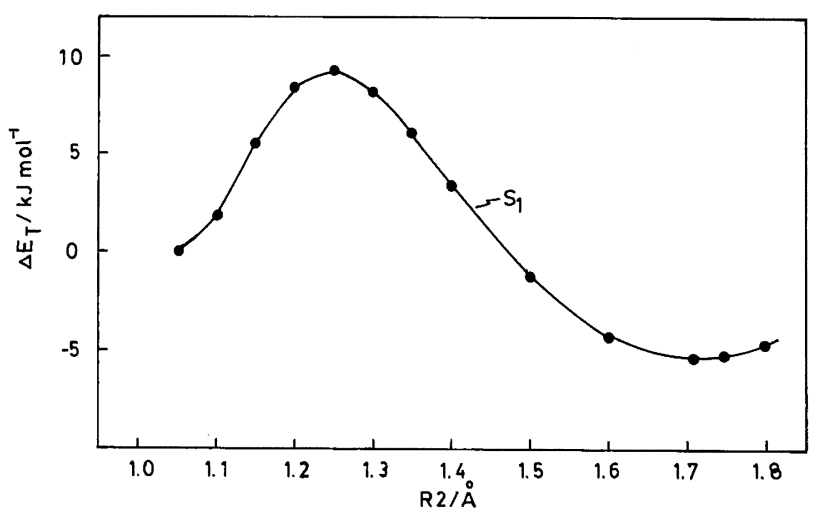

Fig. 5 The potential energy curve of amino-imino tautomerization process from 2-aminopyridinium formate complex to $2(1 H)$-pyridinimine-formic acid complex against the atomic distatnce $R 2$ in the $S_{1}$ state.
離 R2 に対してプロットした. Fig. 5 に扎いて1.25 Aにポテンシ ヤル障壁があり，その高さは9.23 kJ mol-1であり，アミノ体か らカチオン体のボテンシャル障壁と比ぺてエネルギ一的には高い が， $\mathrm{S}_{0}$ 状態に打ける対応する障壁 $\left(39.0 \mathrm{~kJ} \mathrm{~mol}^{-1}\right)$ と比べると非 常に低い、このポテンシャル障壁を越えるとボテンシャル曲線は 緩やかに低下し, 1.707 Aにボテンシャルミニマムを示してい る.このミニマムの位直はイミノ体に対応している．注目される ことは $\mathrm{S}_{1}$ 状態に拉いてイミノ体がカチオン体より $5.36 \mathrm{~kJ} \mathrm{~mol}^{-1}$ エネルギー的には安定であり，また明瞭なボテンシャルミニマム を有する点である。したがって，アミノ体から生成したカチオン 体はさらに安定なイミノ体へ異性化する．また $\mathrm{S}_{1}$ 状態に掞いて むイミノ体はカチオン体を反応中間体として生成することであ る.

先に $\mathrm{S}_{0}$ 状態の 2-アミノピリシンーギ酸系の互変異性における 反応経路 R1 と R2 に対するポテンシャル曲線3をを示したか， Fig. 6 に $\mathrm{S}_{0}$ と $\mathrm{S}_{1}$ 状態を含めて互变異性反応の経路 R1 と R2 に 対するポテンシャル曲線を示した. Fig. 6 では $\mathrm{S}_{0}$ と $\mathrm{S}_{1}$ 状態にお けるアミノ体の全エネルギーを基準として複合体の全エネルギー をプロットした．反応経路 R2 はカチオン体に対する R2 の值 (1.023 $\left.\AA\left(\mathrm{S}_{0}\right) ; 1.053 \AA\left(\mathrm{S}_{1}\right)\right)$ を基点として変化させた. $\mathrm{S}_{0}$ と $\mathrm{S}_{1}$ 状態の互変異性反応のポテンシャル曲線を比較すると, ボテンシ ヤル障壁は $\mathrm{S}_{1}$ 状態の方が低くアミノーイミノ互変異性は励起状 態では容易に進行することを示している. Fig. 6 を参考にしてイ

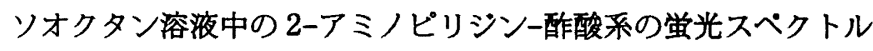
の挙動4)を考察した.

(1) 先の 2-アミノピリシンー酢酸系の蛍光スペクトル変化4) (Fig. 64)を参照)に才いい, 酢酸を添加する前の 2-アミノビリジ ンの蛍光スペクトルは326 $\mathrm{nm}\left(\lambda_{\max }\right)$ に観測される.酢酸添加と ともに，この蛍光スペクトルの強度は急激に低下するのにかかわ らず, $\lambda_{\max }$ の位固は変化しない.このことは326 nm の蛍光スべ

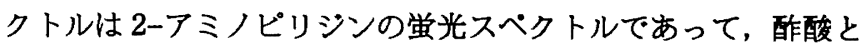

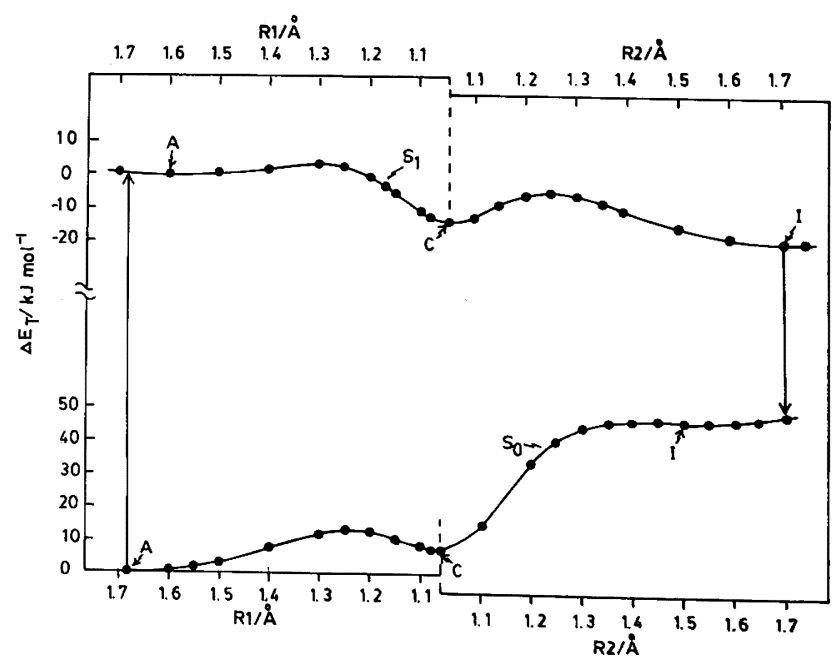

Fig. 6 The potential energy curves of amino-imino tautomerization process from 2-aminopyridine-formic acid complex to $2(1 H)$-pyridinimine-formic acid complex against the atomic distances $R 1$ and $R 2$ in the $S_{1}$ and $S_{0}$ states. The letters $A, C$ and I stand for the amino, caion and imino complexes. 
の間に形成されるアミノ体による蛍光スペクトルではないと考え ることができる．したがって， $\mathrm{S}_{0}$ 状態で䣫酸と水素結合したア ミノ体は $\mathrm{S}_{1}$ 状態へ励起されると，アミノ体から蛍光を発するこ となく無輻射的に $\mathrm{S}_{0}$ 状態に戻る過程と, $\mathrm{S}_{1}$ 状態のボテンシャル 曲線に沿ってアミノ体一>カオン体を経由して, 安定なイミノ 体へと互変異性化反応が起こりイミノ体から蛍光を発する過程が あると考えられる。

(2) Table 1 に示すように $\mathrm{S}_{1}$ 状態において生成したカチオン 体の双極子モーメントの計算值は7.212 D で大きな分極構造を有 している.これに対し，イミノ体の双極子モーメントの計算値は $1.683 \mathrm{D}$ で前者と比べて小さい，先の 2-アミノピリシン $(9.0 \times$ $10^{-5} \mathrm{~mol} \mathrm{dm}^{-3}$ )一酢酸系の蛍光スペクトル変化 ${ }^{4)}$ (Fig. 64) を参照) において，酢酸濃度が $5 \times 10^{-3} \mathrm{~mol} \mathrm{dm}^{-3}$ までは $420 \mathrm{~nm}$ 付近に $\lambda_{\max }$ をむつイミノ体による蛍光スペクトルは酢酸濃度とともに その強度む增加するのに対し， $360 \mathrm{~nm}$ 付近に $\lambda_{\max }$ をむつ力チ才 ン体の蛍光スペクトルは現れていない。酢酸濃度が $2 \times 10^{-2}$ $\mathrm{mol} \mathrm{dm}{ }^{-3}$ になると $360 \mathrm{~nm}$ 付近に $\lambda_{\max }$ をむち, $500 \mathrm{~nm}$ 付近ま で広がったブロードな蛍光スペクトルが観測される．この蛍光ス ペクトルはイミノ体の蛍光スペクトルの示す振動構造を有してい るので，カチオン体とイミノ体の蛍光スペクトルから成ることを 示している．さらに酢酸濃度が増すと， $360 \mathrm{~nm}$ の力チオン体の 蛍光スペクトルの強度が急激に増加するが，イミノ体の領域のス ペクトル変化は見られなくなる．このような酢酸濃度で観測され る䖢光スベクトルはほとんどカチオン体によるむのと考えられ る. 以上の蛍光スペクトルの変化を考えると, 酢酸濃度が低いと きは溶媒の電場の影響は小さいのでイミノ体の安定性が高いが, 酢酸瀑度が增加するにつれて, 溶媒の電場の影響が大きくなり, カチオン体のように大きな双極子モーメントをもつ構造がエネル ギ一的に安定になる．したがって，イミノ体よりカチオン体の濃 度が増加すると考えられる.このためカチオン体の蛍光強度が増 加すると考えられる. 溶質と溶媒の双極子一双極子相互作用によ る安定化のモデルとして, 先に1-メチル-2(1H)-ビリシンイミ ン9)の水, アルコール溶液中でのプロトン移動において，1-メチ ル-2 $(1 H)$-ピリシンイミンー水との間の水素結合体で水からピリ シンイミンの方へプロトン移動が起こると，水素結合体に大きな 双極子モーメントが生じてイオン構造が不安定になりプロトン移 動は困難であるが，溶媒である水の電場を考虑することによっ て, 不安定なイオン構造が安定化され, プロトン移動が進むこと

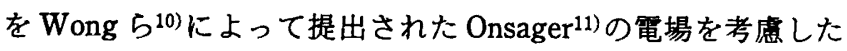
SCRF 法を用いた計算9)で明らかにした．この考え方が 2-アミノ ピリシンー酢酸系のカチオン体とイミノ体の安定性を考える場合 において溶媒効果を考虑することで，カチオン体が安定になると 考えると蛍光スペクトルの挙動が説明できる.

（3）すでに $\mathrm{S}_{0}$ 状態において酶酸添加によってアミノ体を通し てカチオン体 ${ }^{3)}$ が生成することを明らかにしたが，このことは 2-アミノピリシンー酢酸系を励起した場合, アミノ体のほかにカ チオン体む $\mathrm{S}_{1}$ 状態に励起される可能性を有しており，特に酢酸 濃度が増加するとともにその可能性は増加するむのと思われる. このことはカチオン体の生成は $S_{1}$ 状態において，アミノ体を通 して生成する過程の外に, $\mathrm{S}_{0}$ 状態から直接励起される過程も考 虑することが必要と考えられる。

以上のことから，2-アミノピリシンー酶酸系の蛍光スペクトル
は酶酸濃度が増加するにつれて，イミノ体の蛍光からカチオン体 の蛍光へ変化することが考えられる.

\section{3 結 論}

以上の結果からつぎのような結論が得られた.

(1) $\mathrm{S}_{1}$ 状態では 2-アミノピリシンより $2(1 H)$-ピリシンイミ ンの方がエネルギー的に安定であるが，ポテンシャルエネルギー 障壁が高いので直接アミノーイミノ互変異性反応が起こることは 困難である.

(2) 2-アミノピリシンは $S_{1}$ 状態に励起されるとピリシン環の $\mathrm{N}$ 原子の塩基性とアミノ基の $\mathrm{H}$ 原子の酸性は基底状態 $\left(\mathrm{S}_{0}\right)$ より 増加する.これらのことは $\mathrm{S}_{1}$ 状態においては酢酸との水素結合 能力は $\mathrm{S}_{0}$ 状態より増加することを示している.

(3) $\mathrm{S}_{1}$ 状態に抢いてはキ酸との間にアミノ体，カチオン体な らびにイミノ体が生成するが，これらの複合体の安定性は アミ ノ体くカチオン体くイミノ体 の順序になっており， $\mathrm{S}_{0}$ 状態3) と は逆の順序である．このことは酢酸との間の複合体に対しても成 立すると考えられる

(4) $\mathrm{S}_{1}$ 状態に拄いてはアミノ体から直接ダブルプロトン移動 による，一段階の反応でイミノ体が生成することはエネルギー的 に困難であり，アミノ体からプロトン移動により生成したカチオ ン体を中間体としてイミノ体は生成する．このような二段階の生 成機構は $\mathrm{S}_{0}$ 状態3) と同様である.

(5) $\mathrm{S}_{1}$ 状態のアミノ体からカチオン体へのボテンシャル障壁 の高さ, ならびにカチオン体からイミノ体へのポテンシャル障壁 の高さは， $\mathrm{S}_{0}$ 状態にお抽值と比べて低く，励起状態において は互変異性は容易に起こることを示している.

（6） $\mathrm{S}_{1}$ 状態に拉いては酢酸の濃度が低いときはイミノ体がカ チオン体よりも安定であるが, 酢酸濃度が増加するにつれて溶媒 の極性が增すので，極性の大きなカチオン体がイミノ体よりも安 定となり, カチオン体の濃度が増加すると思われる.

（7） $\mathrm{S}_{0}$ 状態に抢いてカチオン体はアミノ体とともに生成する. 酷酸濃度の增加はカチオン体の濃度も增加させるので, $\mathrm{S}_{1}$ 状態 のカチオン体は $\mathrm{S}_{1}$ 状態のアミノ体から生成する過程のほかに， $\mathrm{S}_{0}$ 状態のカチオン体の励起によつて供給される過程が考えられ る.この過程は特に酢酸濃度が高くなるにつれて重要になると思 われる.

この研究は一部住友精化株式会社の研究奖励金によって行っ た.これに対し著者は深く感謝いたします，また，電子計算機使 用にあたり打世話になった，当大学計算センターの金子敏夫氏な らびにその他の皆様にも感謝いたします。

1) K. Inuzuka, A. Fujimoto, Bull. Chem. Soc. Jpn., 63, 971 (1990).

2) A. Fujimoto, K. Inuzuka, Bull. Chem. Soc. Jpn., 64, 3758 (1991).

3）犬塚功三, 日化, 1997, 100.

4) K. Inuzuka, A. Fujimoto, Spectrochim. Acta, 42A, 929 (1986).

5) A. Douhal, S. K. Kim, A. H. Zewail, Nature, 378, 260 (1995).

6) Gaussian 94, Revision C. 3, M. J. Frisch, G. W. Trucks, H. B. Schlegel, P. M. W. Gill, B. G. Johnson, M. A. Robb, J. R. Cheeseman, T. Keith, G. A. Petwrsson, J. A. 
Montgomery, K. Raghavachari, M. A. Al-Laham, V. G. Zakrzewski, J. V. Ortiz, J. B. Foresman, J. Cioslowski, B. B. Stefanov, A. Nanayakkara, M. Challacombe, C. Y. Peng, P. Y. Ayala, W. Chen, M. W. Wong, J. L. Andres, E. S. Replogle, R. Gomperts, R. L. Martin, D. J. Fox, J. S. Binkley, D. J. Defrees, J. Baker, J. P. Stewart, M. Nead-Gordon, C. Gonzalez, J. A. Polple, Gaussian, Inc.,
Pittsburgh PA (1995).

7) A. C. Testa, U. P. Wild, J. Phys. Chem., 83, 3044(1979).

8) S. Babiak, A. C. Testa, J. Phys. Chem., 80, 1882 (1976).

9）犬塚功三, 日化, 1996, 1003.

10) M. W. Wong, M. J. Frisch, K. B. Wiberg, J. Am. Chem. Soc., 113, 4776(1991).

11) L. Onsager, J. Am. Chem. Soc., 58, 1486(1936).

\title{
Molecular Orbital Considerations on the Amino-Imino Tautomerization in the 2-Aminopyridine-Acetic Acid System in the Excited Singlet State
}

\author{
Kozo INUZUKA \\ Department of Materials Science and Engineering, Faculty of Engineering, \\ Tokyo Denki University; Kanda, Chiyoda-ku, Tokyo 101 Japan
}

In order to make clear the amino-imino tautomerization mechanism in the lowest excited singlet state and spectroscopic behavior of fluorescence spectrum of the 2-aminopyridine-acetic acid system, the ab initio molecular orbital calculation at the 6-31G level with a geometry-optimization was carried out for the 2-aminopyridine-formic acid system used as a model system for the 2-aminopyridine-acetic acid system. From calculated results the following conclusions were drawn: (1) The lowest excited singlet state $\left(\mathrm{S}_{1}\right)$ of the optimized models of 2-aminopyridine, 2-aminopyridine-formic acid complex (amino complex), 2-aminopyridinium formate complex (cation complex), and $2(1 H)$-pyridinimine-formic acid complex (imino complex) are of $\pi, \pi^{*}$ character. (2) In the $S_{1}$ state the imino complex is the most stable. It is more stable than the cation complex by $5.36 \mathrm{~kJ} \mathrm{~mol}^{-1}$. The cation complex is more stable than the amino complex by $13.65 \mathrm{~kJ} \mathrm{~mol}^{-1}$ in the same state. The order of stability for these three complexes in the $S_{1}$ state is reverse to that of the corresponding one in the ground state. (3) The calculated potential energy surface suggests that the amino-imino tautomerization may proceed through the cation complex as a reaction intermediate in the $S_{1}$ state. (4) The calculated potential barrier height from the amino complex to the cation complex is $3.78 \mathrm{~kJ} \mathrm{~mol}^{-1}$ in the $\mathrm{S}_{1}$ state. The potential barrier height is very low in comparing with the corresponding one $\left(13.10 \mathrm{~kJ} \mathrm{~mol}^{-1}\right)$ in the ground state. (5) The potential barrier height from the cation complex to the imino complex is $9.23 \mathrm{~kJ} \mathrm{~mol}^{-1}$, which corresponds to the value of $39.00 \mathrm{~kJ} \mathrm{~mol}^{-1}$ in the ground state. (6) The potential barrier heights from the amino complex to the imino complex in the $S_{1}$ state are much lower than the corresponding ones in the ground state. (7) The order of stability among the three complexes in the $S_{1}$ state is consistent with that concluded from the spectroscopic behavior of the fluorescence spectrum of 2-aminopyridine in the low concentration of acetic acid. As the concentration of acetic acid increases, the cation complex may be more stabilized in energy than the imino complex due to the dipole-dipole interaction between the solute and solvent, because the cation complex has the largest dipole moment among the three complexes. Therefore, the order of stability may be as the cation complex $>$ the imino complex $>$ the amino complex. This order of stability is consistent with that concluded from the behavior of the fluorescence spectrum of 2aminopyridine in the higher concentration of acetic acid. 